\title{
Investor Protection and Crowdfunding
}

By Mirzha de Manuel

The "crowdfunding" buzzword has been heard more often in recent months. In October 2013, the US Securities and Exchange Commission (SEC) proposed rules as directed by the Jumpstart Our Business Startups (JOBS) Act that would allow crowdfunding from the general public, and the European Commission launched a consultation inviting citizen input on the value of possible action to promote crowdfunding in Europe. CFA Institute is paying close attention to these regulatory initiatives, in particular their potential impact on investor protection and their potential to stimulate economic growth and job creation.

Crowdfunding involves many individuals pooling small amounts of money to finance an initiative. It sometimes has a pro-bono or "socially conscious" vein to it, with funders not seeking any return or compensation. In other cases, crowdfunding platforms are used as a tool to raise equity or debt, typically by small entrepreneurs.

Because crowdfunding is a young industry undergoing a continuous process of innovation, policymakers on both sides of the Atlantic are tackling it for the first time, following divergent approaches.

In the United States, the SEC is seeking to implement a safe harbour from US securities rules for companies raising up to $\$ 1$ million through registered platforms. (For comparison, the average size per equity campaign in the EU is $€ 50,000$, but it can reach $€ 5$ million in some countries. The EU, which is at a much earlier stage in the process relative to the United States, is consulting on all forms of crowdfunding, but some member states have already come up with their own approaches.)

Political interest in crowdfunding comes from its potential to help bridge the funding gap for small businesses and entrepreneurs. And while this potential may be significant, it does not come without risk to citizens-who, through crowdfunding, turn into direct lenders or investors, many times without appropriate knowledge and experience. The UK Financial Conduct Authority estimates that 50\% to $70 \%$ of new ventures collapse.

From the inception of the US JOBS Act, CFA Institute has been vocal on potential risks for investors. And CFA Institute has not stood alone: In March 2013, former SEC chair Mary Schapiro warned the law's scope was "so broad that it would eliminate important protections for investors in very large companies." In effect, the JOBS Act provides exemptions for companies with up to $\$ 1$ billion in annual revenue-well above the threshold to receive SME (smalland medium-sized enterprises) support in Europe (where the threshold is $€ 50$ million). Moreover, the JOBS Act opens crowdfunding to companies of any size.

In the European Union, the Prospectus Directive provides full exemption for issuances under $€ 100,000$ in 12 months. In addition, the Directive does not apply to issuances under $€ 5$ million, but member states may impose their own requirements. The diversity of national rules makes it difficult for SMEs to seek funding across Europe. To increase investor interest in SMEs, a single market would reduce differences across a wider pool of issuers.

Crowdfunding platforms themselves also need a single market. Their business models rely on bringing together large number of issuers and investors. In Europe, however, platforms are currently operating under disparate national rules or under exceptions to those rules. The lack of common rules on platforms adds complexity to the market and makes the emergence of EU-wide operators unlikely, to the detriment of issuers and investors because of access issues and increased cost.

\section{BECAUSE CROWDFUNDING IS A YOUNG} INDUSTRY UNDERGOING A CONTINUOUS PROCESS OF INNOVATION, POLICYMAKERS ON BOTH SIDES OF THE ATLANTIC ARE TACKLING IT FOR THE FIRST TIME, FOLLOWING DIVERGENT APPROACHES.

Italy was the first country in Europe to devise a specific framework for crowdfunding. Qualifying companies (those with no more than $€ 5$ million in sales) may raise up to $€ 5$ million. They must also fulfil strict requirements to demonstrate that they are new ventures, employing highly qualified staff and investing on research and development. In order to protect retail investors, an investment professional needs to subscribe at least $5 \%$ of each issuance so that at least one due diligence is carried out.

The United Kingdom has followed suit and proposed to open equity-based platforms to retail investors who self-certify their sophistication or commit to invest no more than $10 \%$ of their net investible portfolio in unlisted shares. It is unclear, however, how these limits will be enforced and supervised, and the burden of due diligence is placed indirectly on platforms.

In sum, a scattered crowdfunding market will be a disservice to investors and entrepreneurs in Europe. Action is therefore needed to come up with a reasonable framework, striking the right balance between investor protection and access to investment opportunities. Over the coming months, CFA Institute will engage with regulators in Europe and the United States to communicate the investor perspective.

Mirzha de Manuel is director of capital markets policy for CFA Institute. 